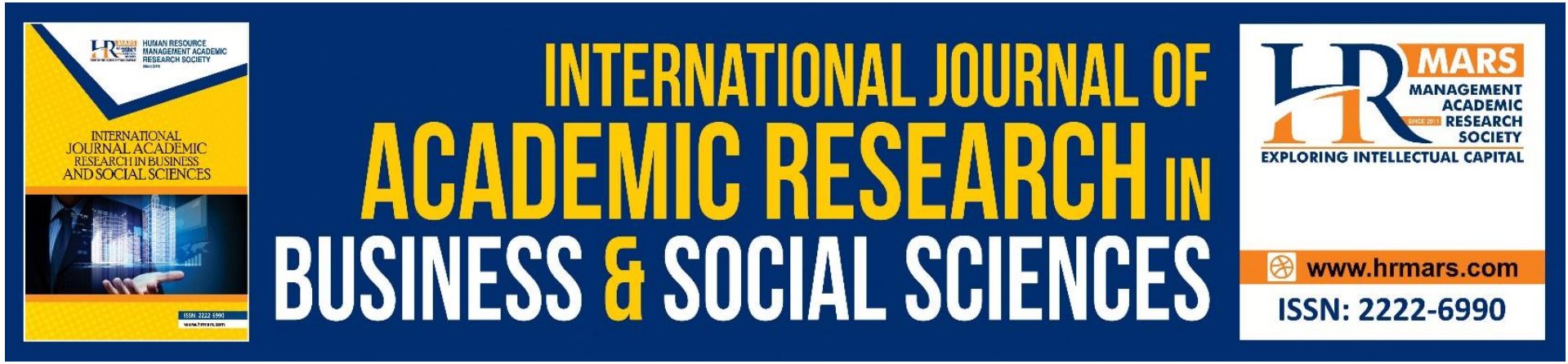

\title{
Effectiveness of Education and Spiritual Rehabilitation in Henry Gurney School Telok Mas Melaka
}

Nurliana Suhaini, Syazwana Aziz, Faudziah Yusof, Siti Marhamah Kamarul Arifain, Nuratiqah Suhaini

To Link this Article: http://dx.doi.org/10.6007/IJARBSS/v11-i8/10894

DOI:10.6007/IJARBSS/v11-i8/10894

Received: 15 June 2021, Revised: 18 July 2021, Accepted: 12 August 2021

Published Online: 30 August 2021

In-Text Citation: (Suhaini et al., 2021)

To Cite this Article: Suhaini, N., Aziz, S., Yusof, F., Arifain, S. M. K., \& Suhaini, N. (2021). Effectiveness of Education and Spiritual Rehabilitation in Henry Gurney School Telok Mas Melaka. International Journal of Academic Research in Business and Social Sciences, 11(8), 1832-1839.

Copyright: @ 2021 The Author(s)

Published by Human Resource Management Academic Research Society (www.hrmars.com)

This article is published under the Creative Commons Attribution (CC BY 4.0) license. Anyone may reproduce, distribute, translate and create derivative works of this article (for both commercial and non-commercial purposes), subject to full attribution to the original publication and authors. The full terms of this license may be seen at: http://creativecommons.org/licences/by/4.0/legalcode

Vol. 11, No. 8, 2021, Pg. 1832 - 1839

Full Terms \& Conditions of access and use can be found at http://hrmars.com/index.php/pages/detail/publication-ethics 


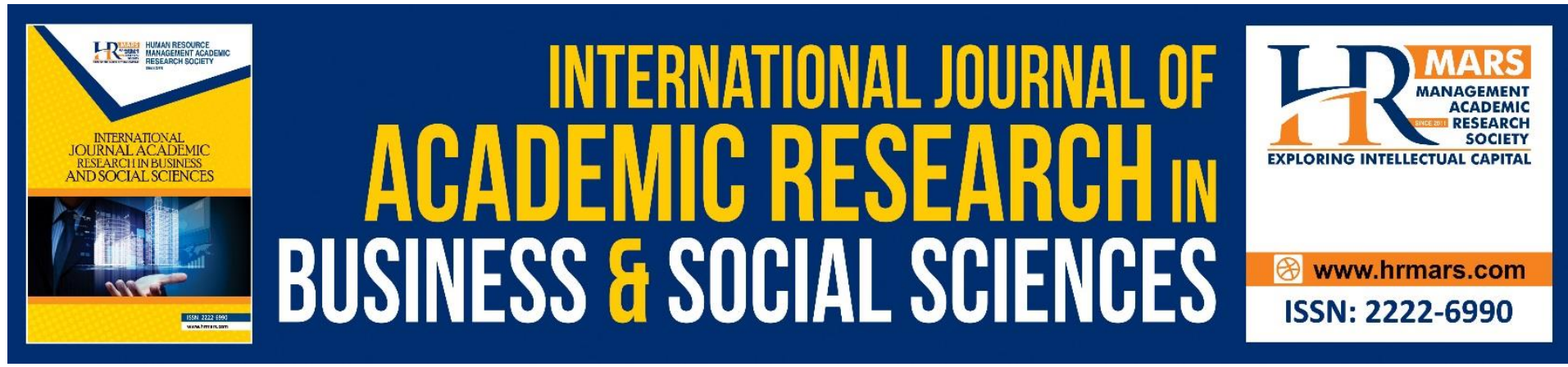

\title{
Effectiveness of Education and Spiritual Rehabilitation in Henry Gurney School Telok Mas Melaka
}

\author{
Nurliana Suhaini, Syazwana Aziz, Faudziah Yusof, Siti \\ Marhamah Kamarul Arifain, Nuratiqah Suhaini \\ Kolej Universiti Islam Melaka \\ Email: nurliana@kuim.edu.m
}

\begin{abstract}
This article focuses on the effectiveness of education and spiritual rehabilitation in Henry Gurney School (SHG) Telok Mas Melaka. Education and spiritual rehabilitation are programs which will be carried out by SHG residents to correct all past mistakes and thus make SHG residents better prepared to continue living later when they are released. Effectiveness is seen through the activities participated by the residents, namely formal education and informal education. ${ }^{1}$ The important essence of the effectiveness of this education and spiritual recovery is to ensure that the occupants can balance present and future education. Eventually SHG residents can live their new lives without repeating past mistakes as a result of the knowledge gained during their living in Henry Gurney School.
\end{abstract}

\section{Introduction}

Education is an activity of development and nurturing of thinking and natural powers through planned learning, including formal education and non-formal education. ${ }^{2}$ Education is also a process of gaining important knowledge in human life. In fact, there is no denying that education will take place throughout human life, as early as in the mother's womb until the end of life. Therefore, all human beings regardless of age of rank and wealth will go through this journey of life including the residents of SHG. This definition of education is also supported by www.dictionary.com; Education refers to:

"the act or process of imparting or acquiring general knowledge, developing the powers of reasoning and judgement, and generally of preparing oneself or others intellectually for mature life." 3

Education gives the meaning that one process of conveying and acquiring knowledge to develop human intellect and self-confidence. As a result, it will increase the maturity to give opinions and argue during real life. Thus, education clearly means all the experiences gained through the senses and thus affect human thinking. Knowledge, skills and noble values will be inherited from generation to generation in the process of developing the nation's civilization continuously. 
In line with that, SHG residents also did not miss out on getting an education despite undergoing rehabilitation. This is because education aims to develop human beings based on nature and build the harmony in every human being. This harmony will actually build life and support and uphold the principles of justice and truth. There is no term for failure forever in life even if you have experienced failure during adolescence. Therefore, education is the rights to everyone as long as one strives to obtain that knowledge.

Restoration, in the dictionary of the council, means something or an act of restoring something. This concept of recovery also carries the meaning that the process of human education with a focus on the physical and spiritual aspects in accordance with the function and role of each component accurately. This suitability results in each component developing as the original purpose of the occurrence of each component. This in turn creates strong human beings in all aspects who are finally able to contribute to religion and society. Hence, the purpose of education and spiritual rehabilitation as supplies and to ensure the future of a SHG resident bright when he is free. SHG residents will be exposed to two forms of Education, namely formal education (academic) and skills training such as Technical, Agriculture and Vocational. In addition to education, another form of rehabilitation given to SHG residents is by providing religious guidance, counselling, also not to miss punishment as a lesson not to continue committing the same offense.

\section{The Importance of The Education in Henry Gurney School in Melaka}

The importance of this study is conducted as a contribution to the writing in the history's field.

Hence, it will give significant contribution to the writing of the scientific study that will be conducted in the future.

Besides that, this study also will give significant contribution to Henry Gurney School in examining the suitability of the education system and also the activities that have been carried

out, whether it is necessary to improve or restructure or improve so that the basic goals of the establishment of the school is achieved.

Meanwhile, for the Ministry of Education (MOE) as a result of this study, the lack of previous forms of education and rehabilitation activities can be identified and improved so that the goal of establishing Henry Gurney School can be achieved and contribute to the reduction of the admission to the school thus reducing juvenile crime rate in Malaysia.

\section{Objective of The Education in Henry Gurney School in Melaka}

This study aims to achieve several objectives. The objectives of the study are:

1) To explain the effectiveness of the formal education system in Henry Gurney School Telok Mas, Melaka.

2) To explain the effectiveness of the spiritual rehabilitation system in Henry Gurney School Telok Mas, Melaka.

3) To explain the effectiveness of the skills education system in Henry Gurney School Telok Mas, Melaka. 


\section{Effectiveness of Formal Education in Henry Gurney School in Melaka}

In the 1940s era, facilities in prisons such as libraries have been provided to ensure that education is still received even while serving sentences, however stopped due to the destruction of the Japanese occupation in 1941 - 1945. At the same time several moral schools were built in Sungai Buloh and Jeram Mas to restore the morale of juvenile offenders. The school is known as "Approved School" is divided into two grades instead of three grades as in the United Kingdom, the first handles boys aged seven to under 12 and the second handles children aged 12 and under 15 years. ${ }^{4}$ In considering the age limit, the committee feels that the age limit is inappropriate and this view has been confirmed by the Director of Education who has informed the committee that the division at this age will not be able to prevent from the educational organization. In addition, the academic staff of the "Approved School" must be part of the general staff in the Department of Education.

Also, there is the Advanced Approved School specifically for boys and girls who commit serious crimes and need to be given discipline and rehabilitation instead of receiving severe punishment. The advantage of this school is to accept various forms of rehabilitation in order to give them the opportunity to change. In the same sense, the main purpose of this school is also to expose these troubled children to moral education. They are actually lacking in terms of moral education, so it can help them to get a place as a normal society in the community later. However, efforts to restore this facility were continued by rebuilding the library at the detention centre by providing financial funds for the Prisons Department to purchase books or other reading materials. The success of the limelight because the goal of promoting the culture of reading would be continued in detention centres and other departments - such as the Department of Information and associations - other associations also presented all forms of literature in English, Malay, Chinese and Tamil as well as a poster - a poster for libraries - library in prison. 5

\section{[...] Despite serving his sentence in prison, the government has never ignored the right of the 'iron curtain' occupants to continue their education". 6}

Here are the words from the state Deputy Director of Education, Markom Giran because the government provides integrity schools to prisoners, especially SHG residents to continue their academic learning 7 . According to him, the school is in line with the philosophy of "Education is for All" and creates a formal and systematic formal academic education system such as schooling outside the prison. The above is supported by the passage in 'Juvenile Deliquency and Juvenile Welfare Committee Appoitment of Members':

"In a country where primary education is compulsary it is natural to expect

a very low rate of delinquency but this is unfortunately not a practical

possibility in Malaya for many years to come but in considering the case

for compulsory education this fact shouid be borne in mind."8

Therefore, the school in collaboration with the Central Prisons Department has concluded that they need to be given attention so that they do not continue to get bad results ${ }^{9}$. In the early stages, the inhabitants of SHG received an imperfect and illiterate education due to the difficult life in the 1950s era and were not exposed to educational knowledge. ${ }^{10}$ Therefore, re-guidance should be done. In the meantime, he said, a special focus on the illiterate 
through special rehabilitation classes and educational services to prison inmates is a joint obligation by the Special Education Division of the Ministry of Education. ${ }^{11}$

Various types of teaching aids are used such as film screenings on Industrial Arts and Agriculture. Illiterate SHG occupants are taught to read, write and count while SHG occupants with educational backgrounds such as form one, two and three are allowed to take the L.C.E.

and M.C.E but almost all of them failed. Obviously, various efforts are made to provide education to SHG residents but there are some obstacles that cannot be overcome such as:

"A large section of the urban population particularly of the Chinese and Indian population at the moment have no facilities for education and though accommodation, staff and finance are likely to delay any scheme of compulsory education we stress the importance of education as a factor in preventing juvenile delinquency." 12

Furthermore, the effect of lack of teachers, a teacher will teach for several subjects. ${ }^{13}$ In fact, the study time set is also only three hours a day from $8.00 \mathrm{am}$ to $11.00 \mathrm{am}$. The above constraints cause the quality of education obtained by SHG residents to be low. There are also a few who ignore the needs of this academic education because of the lazy nature, lack of seriousness and also influenced by friends who are not interested in learning. However, efforts to strengthen the education of SHG residents will continue. Teachers strive to provide supports and encouragement to residents in order to continue learning for bright future.

Thus, the efforts made by the Henry Gurney School to increase the effectiveness in formal education, especially academic achievement, namely the practice of the education system is equivalent to the education system under the Ministry of Education Malaysia ${ }^{14}$. This can be proven when one of the residents of SHG got excellent results in the Sijil Pelajaran Malaysia (SPM) examination. ${ }^{15}$ It was acknowledged by one of the former SHG inmates through excellent academic achievement and therefore obtained a licensed release from the prison to continue his studies at a higher education institution. ${ }^{16} \mathrm{In}$ addition, SHG residents who have achieved excellent achievements are also eligible to further their studies at Public and Private Institutions of Higher Learning. ${ }^{17}$

\section{Effectiveness of Spiritual Rehabilitation in Henry Gurney Melaka School}

Religious education and related matters for example are provided in Regulation $147^{19}$, Regulation $148^{20}$, Regulation $149^{21}$ and Regulation $150^{22}$. The process of spiritual recovery in the form of religious and moral education, counseling and guidance were arranged in the daily routine of SHG residents so that they are ready when they return to their families and communities $^{23}$. In order to make SHG residents who are 'new', the role of the family and the surrounding community are very important to provide support. The support is actually the strength for the SHG occupants to be strong and no longer stuck in the juvenile problem ${ }^{24}$. The religious program is a da'wah program that has been organized and organized neatly. ${ }^{25}$ This is because by running a religious program, it is hoped that it can provide further benefits to achieve the goal of da'wah, which is to improve the morale of the residents of the rehabilitation centre. ${ }^{26}$ Therefore, setting clear goals can help the preacher in formulating planning, strategy and form of implementation that will be used to achieve the objectives outlined. ${ }^{27}$ 
In addition, the activity of providing counseling to SHG residents remains tireless and becomes a routine for staff because these efforts are among those that can soften the hearts of SHG residents as well as staff working like their parents during the recovery process. ${ }^{28}$ The fact is that the family is an institution that can provide mental and physical support to SHG residents because of their young age so they need attention, love and support ${ }^{29}$. Therefore, family visits of SHG residents are allowed once every two weeks and usually on weekends.

On the other hand, families are also invited to attend programs run by a moral institution where their children took part in 'Interactive Workshops' which aims to improve skills and provide awareness to parents in order to strengthen their relationship with their children. ${ }^{31} \mathrm{At}$ the same time accepting their child even though they have made mistakes in the past. SHG residents are often exposed to matters related to family relationships during counseling sessions. Family harmony is achieved through good relationships between all family members. These relationships include spiritual (religious), emotional (loving) relationships, respects, education, responsibility as well as the desire for material assets such as food, clothing and so on.

In order to provide confidence even after being placed in a rehabilitation center, the communication aspect is one of the things that are given priority. It has been discussed by Galvin and Brommel in Atwater, E that the forms of communication of each family member are different when interacting with each other. Usually, troubled teenagers come from families with poor communication. Communication between family members fails to be practiced or there is no communication response to each other. Therefore, family communication forms are important not only to convey information, but also to define relationships, boundaries and networks of interactions within the family.

\section{Effectiveness of Skills Education at Henry Gurney School in Melaka}

Juvenile schools are always striving to improve their knowledge and other skills to change themselves and the lives of SHG residents when they are free. In addition to diversifying activities for SHG residents, in fact this activity also aims to unearth the talents in each SHG resident. Even the skills training learned is also expected to avoid feeling bored and stressed all the time undergoing punishment. ${ }^{33}$ Therefore, various types of teaching aids used such as agricultural science, enterprise and skills knowledge. In addition, recreational training was held by creating handicraft classes that were introduced along with the establishment of prison schools. When there are no occupants company manager SHG was first exposed to the science of paint oil paintings and traditional Malay dance. ${ }^{34}$ However, when an enterprise manager arrives, more skills training can be given such as carving, making sculptures, sewing, making carpets, creating graphic designs and others. Recently, SHG has used more modern and modern skills equipment in line with the passage of time. Even more proud is the Henry Gurney Telok Mas Melaka School Institution has received a certificate of appreciation for its service contribution to the frontliner Covid-19 2020. Henry Gurney School, Telok Mas Melaka has donated 500 personal protective clothing (PPE) produced by staff and residents. ${ }^{35}$

This shows that the residents of SHG can indeed be formed and changed for the better with the encouragement and guidance of educators at SHG.Changes about the importance of education are increasingly seen as light because knowledge is actually very important in every human being. Especially in children who are in trouble because without their knowledge they will continue in the darkness and the probability of returning to commit a crime is huge. So, the teaching of religion is becoming more and more important because a 
clean spirituality will give birth to SHG residents who repent and lead to the right path. In the early 50s, SHG residents began to be entrusted to perform Friday prayers at the Pernu Mosque without control. This goes back to the 'Borstal' system practiced which is to give confidence to juveniles. Religious officers are also always invited in the program with SHG residents and not only provided ustaz to lead prayers every day as practiced in the late 1940s.

It is clear that the officers at the Henry Gurney School in Telok Mas, Melaka also in fact never lost hope to form and guide these juvenile offenders to change and not come back to this school as SHG residents. Therefore, after independence, the strategy of prison officers is to give priority in religious knowledge. Religious teachers came to teach SHG residents about how to pray, read the Quran and the science of fardu ain. The written material was given and even the religious teacher never felt tired to give talks and religious knowledge in the hope that the residents of SHG would repent and change. In addition to religious teachers, monks and monks will also be brought to meet and pray with SHG residents who share their religion. After this effort was carried out, only a few did not succeed in recovering spiritually because they were not sincere and earnestly sought the knowledge conveyed. Prison Officers and Sergeants had to impose punishment in the form of violence to change these SHG inmates such as punishing to be segregated from other SHG inmates also known as the 'Closed Borstal System'. ${ }^{36}$

\section{Conclusion}

Based on the discussion related to academic education taught to SHG residents, it is clear that the efforts were made by Henry Gurney's school, however, faced some difficulties at first but eventually sweetness can be enjoyed when the majority of SHG residents repent and become useful when leaving this school only a few people who returned for repeating the mistake. Newly registered SHG residents were also sentenced to hard labor as punishment. However, the punishment will be commuted if it shows positive changes. The punishment is imposed in order to train their souls to be resilient, diligent, diligent and obey all instructions given. Later, SHG residents will be given jobs in several fields according to their respective interests. Among the fields provided such as rattan workshop, wood, motor, and so on.

Their failure was also identified as a result of job activities, namely skill classes that required them to learn job knowledge causing them to be tired and not focused on academics. Furthermore, pre-independence education also does not focus on local knowledge and prioritizes knowledge from the country of origin such as the Chinese and Indians are taught not based on Malaya. These weaknesses actually contributed to the failure of education at the Henry Gurney Telok Mas School, Melaka before Merdeka. However, efforts to change this form of education were finally successfully implemented little by little. In addition, the caning punishment and 'Panel Grade' implemented have also raised awareness among SHG residents not to continue to violate the set rules. This is due to the effect of violating the rules set by some privileges will be withdrawn and cannot go to school, play, watch movies and even punishable by heavy and rough work.

The completeness of the effectiveness of education and spiritual rehabilitation implemented as early as the formation of the school is increasingly showing positive changes from year to year. The government always pays attention to SHG residents even if they have been involved in various offenses. Most SHG residents are involved in this criminal problem due to other factors in their lives. Therefore, by researching and deepening their problems 
and even giving them a good education and encouragement, they have finally borne fruit. The role played by all parties in shaping SHG residents is changing towards this good should be continued because SHG residents are the heirs of the country in the future.

\section{References}

Annual report Federated Malay States (F.M.S). (1905). Kuala Lumpur: Arkib Negara. Salleh, A. G. (1970). Panduan Penjara. Jabatan Penjara Malaysia:Taiping.

Alzahrin, A., \& Nasaruddin, P. (2015). Hikmah masuk Henry Gurney. Scribbr. https://www.bharian.com.my/bhplus-old/2015/06/59497/hikmah-masuk-henrygurney

Garratt, O. V. (1955) Report on the Prison of the Federation of Malaya 1953 \&1954. Kuala Lumpur: Percetakan Kerajaan.

Ghafar, M. (2020). Personal interview [ Former Prison Sergeant Henry Gurney School, Telok Mas. Melaka].

Jabatan Penjara Malaysia Kementerian Dalam Negeri. (2019). Program Halatuju Dan Kerjaya Bersama Orang Diselia Di Pusat Pemulihan Pemasyarakatan Kem Mahkota Kluang, Johor (PPP). Scribbr. http://www.prison.gov.my/ms/arkib/49394-Program-HalatujuDan-Kerjaya-Bersama-Orang-Diselia-Di-Pusat-Pemulihan-Pemasyarakatan \%C2\%A0Kem-Mahkota-Kluang,-Johor-(PPP).

Watson, J. A. F. (1965). The Child and the Magistrate. New Jessed Ed. London: Jonathan Cape. Najeemah, M. Y. (2006). Konsep Pendidikan. Kuala Lumpur: PTS Professional Publishing Sdn. Bhd.

MStar. (2014). http://www.prison.gov.my/ms/arkib/1106-penghuni-sekolah-henry-gurneytelok-mas-melaka-terima-sijil-penghargaan-dari-jabatan-oftalmologi-hospitalmelaka.

Sayuti, R., \& Ying, K. C. (2006). Institusi Keluarga. Kuala Lumpur: Utusan Publicstions \& Distributors Sdn Bhd. 